\title{
Analisis Hasil Belajar: Dampak Pembelajaran Berbantuan Software pada Pembelajaran Statistika
}

\author{
Novalia \\ Universitas Sang Bumi Ruwa Jurai, Jl. Imam Bonjol No.486, Langkapura, Kota Bandar Lampung, \\ Lampung 35118 \\ Correspondent Author: novaliasholehah@gmail.com
}

\begin{abstract}
Abstrak
Penelitian ini bertujuan untuk mengetahui pengaruh penggunaan Excel dan SPSS terhadap hasil belajar mahasiswa pada mata kuliah statistika lanjut. Jenis penelitian ini adalah penelitian kuantitatif dengan desain penelitian eksperimen. Tindakan yang dilakukan merupakan upaya mengembangkan teknologi pembelajaran yaitu pendekatan belajar konstruktivisme yang dikemas dalam pembelajaran statistika melalui penggunaan Excel dan SPSS. Berdasarkan analisis data hasil belajar dari pembelajaran statistika tanpa bantuan program, dengan bantuan program Excel dan SPSS menunjukkan bahwa tidak ada pengaruh yang signifikan penggunaan program Excel dan SPSS terhadap hasil belajar mahasiswa. Ada beberapa hal menyebabkan penggunaan program Excel dan SPSS tidak berpengaruh terhadap hasil belajar mahasiswa yaitu (1) Sarana prasarana yang kurang memadai, (2) kemampuan statistika dasar mahasiswa masih rendah dan (3) minat mahasiswa belajar statistika masih rendah.
\end{abstract}

Kata kunci: Excel, SPSS, Statistika.

\begin{abstract}
This study aims to determine the effect of using Excel and SPSS on student learning outcomes in advanced statistics courses. This type of research is quantitative research with experimental research designs. The action taken is an effort to develop learning technology, namely the constructivism learning approach that is packaged in statistical learning through the use of Excel and SPSS. Based on the analysis of learning outcomes data from statistical learning without the help of programs, with the help of Excel and SPSS programs, there is no significant effect of using Excel and SPSS programs on student learning outcomes. There are several things that cause the use of Excel and SPSS programs do not affect student learning outcomes, namely (1) Inadequate infrastructure, (2) students 'basic statistical skills are still low and (3) students' interest in learning statistics is still low.
\end{abstract}

Keywords: Excel, SPSS, Statistic.

\section{PENDAHULUAN}

Salah satu cabang ilmu matematika adalah statistika. Sebagian besar orang beranggapan bahwa statistika adalah ilmu yang sulit, penuh dengan rumus-rumus rumit yang memerlukan ketelitian dan kecermatan dalam perhitungannya. Hal ini pula yang terjadi pada sebagian mahasiswa yang mengambil mata kuliah statistika matematika II yang masih banyak mendapatkan nilai di bawah ratarata. Selain berdasarkan nilai, rendahnya pemahaman konsep statistika mahasiswa terlihat dari skripsi-skripsi yang ada. Metoda statistik yang dipergunakan dalam pembuktian hipotesis cenderung tidak sesuai dengan bentuk/sifat data penelitian yang ada, serta pengolahan data yang dilakukan secara manual sering terjadi kesalahan dalam perhitungan.

Seiring dengan kemajuan yang pesat dalam bidang teknologi, muncul berbagai program komputer yang dirancang khusus untuk membantu pengolahan data statistik. Pengolahan data statistik menjadi jauh lebih mudah 
dan menyenangkan tanpa mengurangi ketepatan hasil outputnya. Program seperti SPSS (Statistical Product and Service Solution), Excel, Minitab, R dan Amos cukup populer sebagai program komputer statistik yang mampu memproses data statistik secara cepat dan akurat.

Berdasarkan penelitian yang telah dilakukan sebelumnya, penggunaan Excel dan SPSS telah digunakan dalam beberapa penelitian (Frey \& Loots, 2014; Niati, Soelistiyono, \& Ariefiantoro, 2019) dan beberapa penelitian dalam kaitan ilmu statistika(Amalia, 2011; Dirgantoro, Saragih, \& Listiani, 2019; Fitri, 2011; Maryati \& Priatna, 2017; Susanti, Musdi, \& Syarifuddin, 2017; Tayeb, Idris, \& Andi, 2014; Yenni, 2017) serta beberapa penelitian yang bertujuan untuk meningkatkan hasil belajar peserta didik(A.T.Setiawan, 2016; Fitriana \& Ismah, 2016; Jagantara, Prof. Dr. Putu Budi Adnyana, \& Dr. Ni Luh Putu Manik Widiyanti, 2014; Kania, Kartimi, \& Mulyani, 2013; Lipianto et al., 2013; Prihartini \& Mediatati, 2013; Santi, 2016; Sari, Ridlo, \& Utami, 2016; Septiono \& Darminto, 2014; Syaifulloh, 2016). Tetapi penelitian mengenai pengaruh penggunaan Excel dan SPSS terhadap hasil belajar mahasiswa pada mata kuliah statistika lanjut belum pernah dilakukan.

Berdasarkan penelitian terdahulu, keterbaruan penelitian ini adalah untuk melihat pengaruh penggunaan Excel dan SPSS terhadap hasil belajar mahasiswa pada mata kuliah statistika lanjut. Maka, penelitian ini bertujuan untuk mengetahui pengaruh penggunaan Excel dan SPSS terhadap hasil belajar mahasiswa pada mata kuliah statistika lanjut

\section{METODE}

Jenis penelitian yang digunakan adalah penelitian kuantitatif dengan desain penelitian eksperimen. Teknik pengumpulan data dalam penelitian ini adalah tes, dokumentasi dan wawancara. Tindakan yang dilakukan merupakan upaya mengembangkan teknologi pembelajaran yaitu pendekatan belajar konstruktivisme yang dikemas dalam pembelajaran statistika melalui penggunaan Excel dan SPSS. Pembelajaran pada penelitian ini dibagi menjadi 3 (tiga) tahap yaitu tahap 1 (satu) pembelajaran statistika dengan perhitungan tanpa menggunakan program, tahap 2 (dua) pembelajaran statistika dengan perhitungan menggunakan program Excel, dan tahap 3 (tiga) pembelajaran statistika dengan perhitungan menggunakan program SPSS.

Teknik Analisis data yang dipergunakan dalam penelitian ini adalah analisis keragaman (Analysis of Varians/ANOVA), dipakai untuk pengujian lebih dari 2 sampel. ANOVA yang digunakan dalam penelitian ini yaitu ANOVA klasifikasi 1 arah, ANOVA yang didasarkan pada pengamatan 1 kriteria. Hipotesis yang diuji adalah

$H_{0}: \quad \mu_{1}=\mu_{2}=\mu_{3}$ (semua nilai tengah sama)

$H_{1}: \exists \mu_{i} \neq \mu_{j}$ untuk $\mathrm{i} \neq j$ (Ada sekurangkurangnya sepasang nilai tengah $\mu_{i}$ dan $\mu_{j}$ yang tidak sama)

Dimana:

$\mu_{1}:$ nilai tengah hasil belajar tanpa menggunakan program statistika

$\mu_{2}$ : nilai tengah hasil belajar dengan bantuan program excel

$\mu_{3}$ : nilai tengah hasil belajar dengan bantuan program SPSS

Rumus yang digunakan untuk melakukan uji ANOVA disajikan dalam bentuk Tabel 1. 
Desimal, 2 (3), 2019 - 273

Novalia

\begin{tabular}{ccccc}
\hline $\begin{array}{c}\text { Sumber } \\
\text { Keragaman }\end{array}$ & $\begin{array}{c}\text { Jumlah } \\
\text { Kuadrat }\end{array}$ & $\begin{array}{c}\text { Derajat } \\
\text { Bebas }\end{array}$ & Kuadrat Tengah & F hitung \\
kolom & JKK & $\mathbf{k}-\mathbf{1}$ & KTK $=\frac{J K K}{k-1}$ & KTK \\
$\begin{array}{c}\text { Galat } \\
\text { (Error) }\end{array}$ & JKG & $\mathbf{k}(\mathbf{n}-1)$ & $\mathbf{K T G}=\frac{J K G}{k(n-1)}$ & $\mathbf{K T G}$ \\
Total & JKT & $\mathbf{n k - 1}$ & & \\
\hline
\end{tabular}

Dimana :

Jumlah Kuadrat Total (JKT)

$=\sum_{i=1}^{k} \sum_{j=1}^{n} x_{i j}^{2}-\frac{T_{. *}^{2}}{n k}$

Jumlah Kuadrat Kolom (JKK)

$=\frac{\sum_{i=1}^{k} T_{i}{ }^{2}}{n}-\frac{T . .^{2}}{n k}$

Jumlah Kuadrat Galat (JKG)

$=\mathrm{JKT}-\mathrm{JKK}$

Derajat bebas kolom (dbk) $=\mathrm{k}-1$

Derajat bebas total $(\mathrm{dbt}) \quad=\mathrm{nk}-1$

Derajat bebas galat $(\mathrm{dbg}) \quad=\mathrm{dbt}-\mathrm{dbk}$

Kuadrat Tengah Kolom $(\mathrm{KTK})=\frac{\mathrm{JKK}}{\mathrm{dbk}}$

Kuadrat Tengah Galat $(\mathrm{KTG})=\frac{\mathrm{JKG}}{\mathrm{dbg}}$

$\mathrm{F}_{\text {hitung }}=\frac{\mathrm{KTK}}{\mathrm{KTG}}, \mathrm{F}_{\text {tabel }}=\mathrm{F}_{(\alpha, \mathrm{dbk}, \mathrm{dbg})}$

$\mathrm{K}$ = banyaknya kolom/perlakuan

$\mathrm{n} \quad=$ jumlah responden/ banyaknya ulangan

Untuk membuat kesimpulan kita bandingkan nilai $\mathrm{F}_{\text {hitung }}$ dan $\mathrm{F}_{\text {tabel. }}$. Jika $F_{\text {hit }} \leq F_{\text {tabel }}$, maka $H_{0}$ diterima.

Jika hasil ANOVA tolak Ho, maka dilakukan uji lanjut untuk mengetahui pasangan perlakuan yang berbeda nyata. Ada banyak uji lanjut ANOVA antara lain uji Beda Nyata Jujur (Tukey) dan Uji Scheffe. Uji lanjut yang digunakan dalam penelitian ini adalah uji Scheffe dengan hipotesis sebagai berikut:

$$
\begin{array}{ll}
H_{0}: & \mu_{i}=\mu_{j} \\
H_{1}: & \mu_{i} \neq \mu_{j}
\end{array}
$$

Rumus uji Scheffe sebagai berikut:

$$
\begin{aligned}
& F_{\text {hitung }}=\frac{\left(\overline{X_{l}}-\overline{X_{J}}\right)^{2}}{K T G\left(\frac{1}{n_{i}}+\frac{1}{n_{j}}\right)}, \quad F_{\text {tabel }}= \\
& F_{(\alpha, d b k, d b g)}
\end{aligned}
$$

Kriteria uji: Jika $F_{\text {hitung }}>F_{(\alpha, d b k, d b g)}$, maka Ho ditolak.

ANOVA merupakan statistika parametrik sehingga ada asumsi yang harus dipenuhi yaitu asumsi kenormalan dan kehomogenan. Uji kenormalan yang digunakan yaitu uji Liliefors dengan rumus sebagai berikut:

$$
\begin{aligned}
& L_{\text {hitung }}=\operatorname{Max}|f(z)-S(z)|, L_{\text {tabel }}= \\
& L_{(\alpha, n)}
\end{aligned}
$$

Dengan hipotesis:

$H_{0}$ : data mengikuti sebaran normal

$H_{1}$ : data tidak mengikuti sebaran normal

Kriteria uji: Jika $L_{\text {hitung }} \leq L_{\text {Tabel }}$, maka $H_{0}$ diterima

Asumsi kehomogenan menggunakan uji Bartlet dengan rumus sebagai berikut:

$$
\begin{gathered}
X_{\text {hitung }}^{2}=\ln (10)\{B- \\
\left.\sum_{i=1}^{k} d k \operatorname{LogS}^{2}\right\}, X_{\text {tabel }}^{2}=X_{(\alpha, k-1)}^{2}
\end{gathered}
$$

Hipotesis:

$H_{0}$ : Data berasal dari populasi yang homogen

$H_{1}$ : Data tidak berasal dari populasi yang homogen

Kriteria uji: Jika $X_{\text {hitung }}^{2} \leq X_{\text {tabel }}^{2}$, maka $H_{0}$ diterima.

Jika asumsi ANOVA tidak terpenuhi, maka solusinya adalah mentransformasi data atau menggunakan uji statistika nonparametrik. Uji statistika nonparametrik yang tepat digunakan adalah uji Kruskal-Wallis. Uji KruskalWallis adalah uji non-parametrik yang digunakan untuk menguji $\mathrm{k}$ sampel independen. Rumus umum yang digunakan pada uji Kruskal-Wallis adalah:

$$
\begin{aligned}
& \mathrm{H}=\frac{12}{N(N+1)} \sum_{i=1}^{k} \frac{R_{i}^{2}}{n_{i}}-3(N+1), \\
& \chi_{\text {tabel }}^{2}=\chi_{(\alpha, k-1)}^{2}
\end{aligned}
$$


Hipotesis:

$H_{0}: \quad \mu_{1}=\mu_{2}=\mu_{3}$ (semua nilai tengah sama)

$H_{1}: \quad \exists \mu_{i} \neq \mu_{j}$ untuk $\mathrm{i} \neq j$ (Ada sekurangkurangnya sepasang nilai tengah $\mu_{i}$ dan $\mu_{j}$ yang tidak sama)

Keterangan:

$R_{i}=$ jumlah peringkat contoh ke-i

$\mathrm{N}=\sum_{i=1}^{k} n_{i}$

$\mu_{1}$ : nilai tengah hasil belajar tanpa menggunakan program statistika

$\mu_{2}$ : nilai tengah hasil belajar dengan bantuan program excel

Keriteria uji: Jika $\mathrm{H}<\chi_{\text {tabel }}^{2}$, maka $H_{0}$ diterima artinya semua nilai tengah sama.

\section{HASIL DAN PEMBAHASAN Hasil Penelitian}

Penelitian ini terdiri dari tiga tahap pembelajaran yaitu tahap pertama mahasiswa diberikan materi statistika dengan perhitungan tanpa menggunakan program, tahap kedua menggunakan program Excel dan tahap ketiga dengan SPSS. Setiap tahap terdiri dari 3 pertemuan yaitu 2 pertemuan materi dan 1 pertemuan tes. Hasil belajar pada tahap pertama terlihat pada Gambar 1. berikut ini.

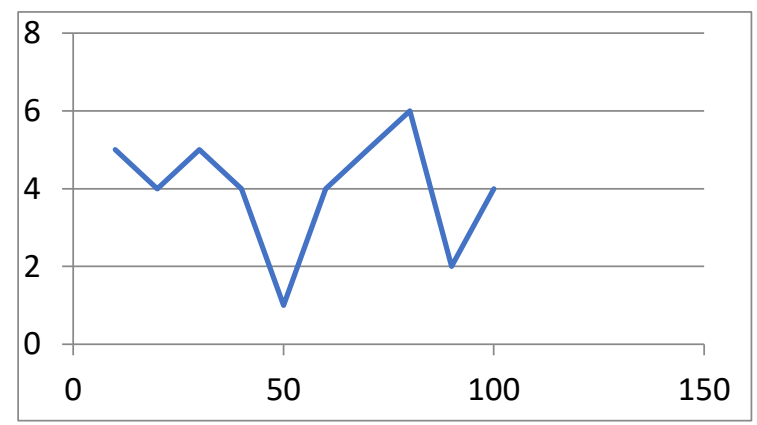

Gambar 1. Grafik Hasil Belajar Tahap I

Berdasarkan Gambar 1, memperlihatkan sebaran hasil belajar mahasiswa pada tahap I. Pada Gambar 1. terlihat bahwa 4 orang mahasiswa memperoleh hasil belajar tertinggi yaitu 100 dan 5 orang mahasiswa memperoleh hasil belajar terendah yaitu 10. Paling banyak mahasiswa memperoleh hasil belajar 80 yaitu 6 orang mahasiswa dan paling sedikit mahasiswa memperoleh hasil belajar 50 yaitu 1 orang mahasiswa. Setelah tahap I berakhir, dilanjutkan tahap berikutnya yaitu tahap II. Pada tahap II, mahasiswa belajar materi statistika dan mencoba perhitungan dengan menggunakan Excel. Hasil belajar pada tahap II terlihat pada Gambar 2.

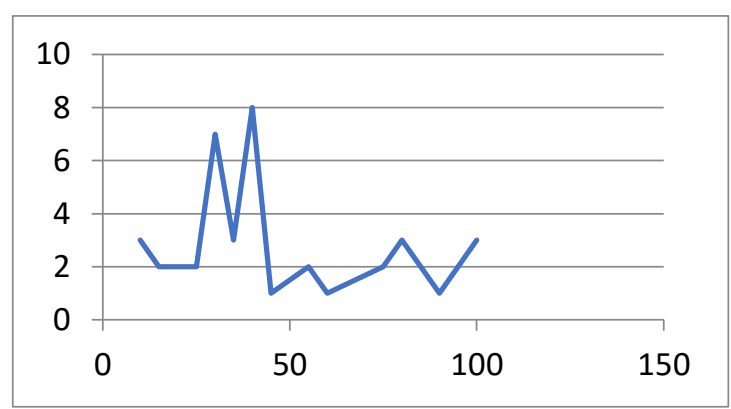

Gambar 2. Grafik Hasil Belajar Tahap II

Berdasarkan Gambar 2. memperlihatkan sebaran hasil belajar mahasiswa pada tahap II. Pada Gambar 2. terlihat bahwa 3 orang mahasiswa memperoleh hasil belajar tertinggi yaitu 100 dan 3 orang mahasiswa memperoleh hasil belajar terendah yaitu 10. Paling banyak mahasiswa memperoleh hasil belajar 40 yaitu 8 orang mahasiswa dan paling sedikit mahasiswa memperoleh hasil belajar 45 dan 60 yaitu masingmasing 1 orang mahasiswa. Pada Gambar.1 terlihat sebaran hasil belajar mahasiswa hampir merata dari 0 sampai 100, sedangkan pada Gambar.2 sebaran hasil belajar mahasiswa tidak merata lebih banyak mahasiswa yang memperoleh nilai antara 0 sampai 40 . Tahap terakhir dalam penelitian ini yaitu tahap III, mahasiswa belajar materi statistika dan mencoba perhitungan dengan menggunakan SPSS. Hasil belajar pada tahap III terlihat pada Gambar.3 berikut.

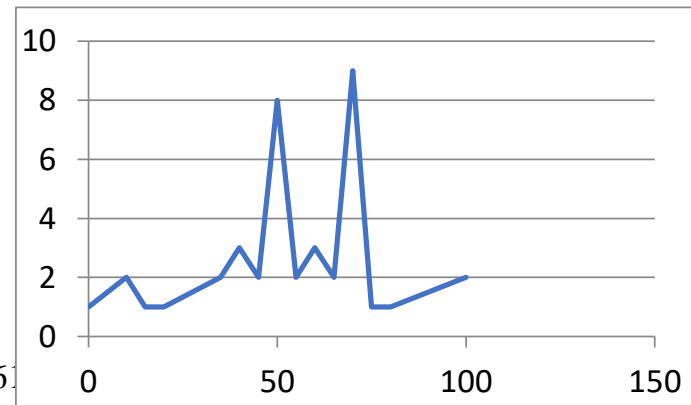


Gambar 3. Grafik Hasil Belajar Tahap III

Berdasarkan Gambar 3. memperlihatkan sebaran hasil belajar mahasiswa pada tahap III. Pada Gambar 3. terlihat bahwa 2 orang mahasiswa memperoleh hasil belajar tertinggi yaitu 100 dan 1 orang mahasiswa memperoleh hasil belajar terendah yaitu 0 . Paling banyak mahasiswa memperoleh hasil belajar 70 yaitu 9 orang mahasiswa dan paling sedikit mahasiswa memperoleh hasil belajar 15 dan 20 yaitu masingmasing 1 orang mahasiswa. Pada Gambar.3 terlihat sebaran hasil belajar mahasiswaterbanyak terletak antara 45 sampai dengan 75 .

Rata-rata dan median merupakan ukuran pemusatan data yang dianggap mewakili suatu data. Rata-rata hasil belajar pada tahap I dan III sama yaitu 53.5, sedangkan rata-rata pada tahap kedua menurun yaitu sebesar 44.5. Median pada tahap I lebih tinggi dibandingkan kedua tahap lainnya yaitu sebesar 60. Median terendah ada pada tahap II yaitu 40 , sedangakan median pada

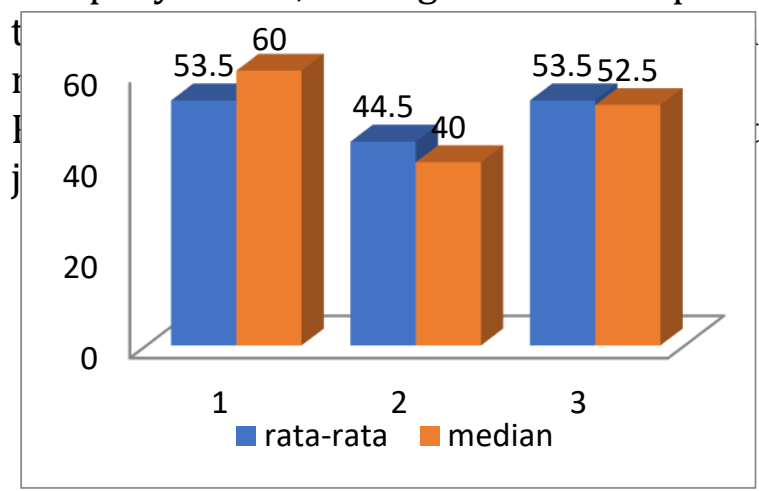

Gambar.4 Rata-rata dan Median Tahap I, Tahap II dan Tahap III

\section{Analisis Data}

Analisis data yang digunakan dalam penelitian ini adalah ANOVA, oleh karena itu langkah pertama yang harus dilakukan adalah menguji asumsi-asumsi dari ANOVA yaitu asumsi normalitas dan homogenitas. Pengujian normalitas data dengan SPSS dapat dilihat pada Tabel 2.

Tabel 2. Uji Normalitas

\begin{tabular}{|c|c|c|c|c|c|c|c|}
\hline & \multirow{2}{*}{ pembelajaran } & \multicolumn{3}{|c|}{ Kolmogorov-Smirnova } & \multicolumn{3}{|c|}{ Shapiro-Wilk } \\
\hline & & Statistic & $\mathrm{df}$ & Sig. & Statistic & df & Sig. \\
\hline \multirow{3}{*}{$\begin{array}{l}\text { hasil_ } \\
\text { belajar }\end{array}$} & tanpa program & .135 & 40 & .062 & .923 & 40 & .009 \\
\hline & Excel & .243 & 40 & .000 & .889 & 40 & .001 \\
\hline & Spss & .137 & 40 & .056 & .949 & 40 & .069 \\
\hline \multicolumn{8}{|c|}{ a. Lilliefors Significance Correction } \\
\hline
\end{tabular}

Pada Tabel 2. terlihat bahwa nilai signifikan untuk data hasil belajar tanpa program dan hasil belajar dengan Excel adalah 0.009 dan 0.001. Nilai signifikan untuk hasil belajar tanpa program dan dengan program Excel kurang dari alpha, sehingga Ho ditolak artinya kedua kelompok data tidak berdistribusi normal.
Nilai signifikan untuk hasil belajar dengan program SPSS lebih dari alpha, sehingga Ho diterima artinya kelompok data berdistribusi normal. Asumsi kenormalan tidak terpenuhi untuk semua kelompok data. Berikutnya menguji homogenitas data, hasil uji homogenitas dapat dilihat pada Tabel 3 . 
Desimal, 2 (3), 2019 - 276

Novalia

Tabel 3. Uji Homogenitas

\begin{tabular}{cccccc}
\hline & & $\begin{array}{c}\text { Levene } \\
\text { Statistic }\end{array}$ & df1 & df2 & Sig. \\
& Based on Mean & 4.527 & 2 & 117 & .013 \\
Based on Median & 3.618 & 2 & 117 & .030 \\
hasil_belajar & $\begin{array}{c}\text { Based on Median and } \\
\text { with adjusted df }\end{array}$ & 3.618 & 2 & 112.459 & .030 \\
& Based on trimmed mean & 4.452 & 2 & 117 & .014 \\
\hline
\end{tabular}

Pada Tabel 3 terlihat bahwa nilai signifikan untuk ketiga kelompok data adalah 0.013 , nilai signifikan kurang dari alpha, sehingga Ho ditolak artinya data tidak berasal dari populasi yang homogen. Kedua asumsi ANOVA tidak terpenuhi, oleh karena itu analisis selanjutnya mentransformasi data atau Kruskall Wallis. Berbagai transformasi data dilakukan, namun kedua asumsi masih tidak terpenuhi oleh karena itu langkah selanjutnya melakukan uji Kruskall Wallis. Hasil uji Kruskal Wallis dengan SPSS dapat dilihat pada Tabel 4.

Tabel 4. Uji Kruskal Wallis

\begin{tabular}{cc} 
& hasil_belajar \\
Chi-Square & 4.004 \\
df & 2 \\
Asymp. Sig. & .135 \\
\hline
\end{tabular}

a. Kruskal Wallis Test

b. Grouping Variable: pembelajaran

Berdasarkan Tabel 4. terlihat bahwa nilai signifikan dari uji Kruskall Wallis adalah 0.135. Nilai signifikan lebih dari alpha sehingga Ho diterima artinya tidak ada perbedaan yang berarti dari rata-rata hasil belajar pada tahap I (pembelajaran tanpa program), tahap II (dengan Excel) dan tahap III (dengan SPSS) atau dengan kata lain tidak ada pengaruh yang signifikan penggunaan Excel dan SPSS terhadap hasil belajar mahasiswa pada mata kuliah statistika lanjut

\section{Pembahasan}

Hasil dari analisis data yang telah dilakukan dengan bantuan program SPSS menyimpulkan bahwa tidak ada pengaruh yang signifikan penggunaan Excel dan SPSS terhadap hasil belajar mahasiswa pada mata kuliah statistika lanjut. Berdasarkan observasi dan wawancara yang dilakukan ada beberapa hal yang menyebabkan kurang efektifnya pembelajaran statistika lanjut dengan bantuan Excel dan SPSS. Pertama, kurang lengkapnya sarana prasarana. Laboratorium komputer memadai dan tidak semua mahasiswa memiliki laptop. Hal ini menyebabkan mahasiswa kurang melakukan praktek, padahal diperlukan praktek berulang-ulang agar siswa memahami analisis statistika dengan Excel dan SPSS. Nilai rata-rata pada pembelajaran dengan bantuan Excel paling rendah dibandingkan pembelajaran tanpa bantuan program dan pembelajaran dengan bantuan program SPSS. Perhitungan statistika dengan menggunakan Excel seharusnya membuat mahasiswa lebih mengerti materi statistika karena mahasiswa membuat sendiri langkah perlangkah sesuai dengan rumus-rumus statistika yang ada, namun perhitungan statistika dengan excel membutuhkan ketelitian yang tinggi. Jika salah satu langkah, maka akan 
mempengaruhi hasil perhitungan. Berdasarkan pengamatan peneliti dari softcopy posttest pembelajaran statistika dengan bantuan Excel, sebagian besar mahasiswa melakukan kesalahan pada langkah-langkah awal perhitungan sehingga hasil akhirnya kurang tepat.

Kedua, kemampuan statistika dasar masih rendah. Hal ini terlihat pada saat pembelajaran banyak istilah-istilah statistika dasar yang belum diketahui mahasiswa, sehingga dosen harus mengulang kembali teori yang seharusnya sudah dipahami mahasiswa. Mata kuliah statistika lanjut merupakan lanjutan dari mata kuliah statistika dasar, sehingga materi kedua mata kuliah saling berkaitan. Pada mata kuliah statistika dasar materi yang dibahas mengenai statistika deskriptif dan peluang yang meliputi istilah-istilah dasar statistika, ukuran pemusatan data, ukuran penyebaran data, peluang dan distribusi peluang. Pada mata kuliah statistika lanjut membahas statistika inferensia yang meliputi pengujian hipotesis satu sampel, pengujian hipotesis dua sampel, korelasi, regresi dan anova.

Ketiga, minat mahasiswa belajar statistika masih rendah. Hal ini dilihat dari tingkat kehadiran mahasiswa, setiap pertemuan selalu ada mahasiswa yang tidak hadir dengan berbagai alasan. Materi statistika lanjut saling berkait satu sama lain, jika mahasiswa tidak hadir pada suatu pertemuan maka mahasiswa susah untuk memahami materi pada pertemuan selanjutnya. Berdasarkan pengamatan peneliti, mahasiswa yang tidak masuk pada suatu pertemuan tidak berusaha memahami materi yang telah dibahas pada pertemuan tersebut.

\section{SIMPULAN DAN SARAN}

Berdasarkan analisis data yang telah dilakukan dapat disimpulkan bahwa tidak ada pengaruh yang siginifikan penggunaan Excel dan SPSS terhadap hasil belajar mahasiswa pada mata kuliah statistika lanjut. Rata-rata hasil belajar statistika lanjut melalui pembelajaran tanpa bantuan program, dengan program Excel dan program SPSS tidak jauh berbeda. Ada beberapa hal menyebabkan penggunaan program Excel dan SPSS tidak berpengaruh terhadap hasil belajar mahasiswa yaitu (1) Sarana prasarana yang kurang memadai, (2) kemampuan statistika dasar mahasiswa masih rendah dan (3) minat mahasiswa belajar statistika masih rendah.

Saran yang dapat diberikan pada penelitian selanjutnya yaitu hendaknya menggunakan program-program statistika yang lainnya seperti program $\mathrm{R}$, SAS, EVIEWS dan lain sebagainya dalam penelitian selanjutnya.

\section{DAFTAR PUSTAKA}

A.T.Setiawan. (2016). Pengaruh Pembelajaran Kooperatif Two Stay Two Stray Berpendekatan Ansets Terhadap Hasil Belajar Kimia Siswa SMA N 1 Comal. Jurnal Inovasi Pendidikan Kimia, 6(1).

Amalia, F. (2011). Pengembangan Perangkat Pembelajaran Statistika Dasar Bermuatan Pendidikan Karakter Dengan Metode Problem Based Learning. Jurnal PP, 1(2), 1-7.

Dirgantoro, K. P. S., Saragih, M. J., \& Listiani, T. (2019). Analisis Kesalahan Mahasiswa Pgsd Dalam Menyelesaikan Soal Statistika Penelitian Pendidikan Ditinjau Dari Prosedur Newman [An Analysis of Primary Teacher Education Students Solving Problems In Statistics For Educational Research Using The Newman Procedure. Johme: Journal of Holistic Mathematics Education, 2(2), 1-14.

Fitri, A. (2011). Pengembangan Perangkat Pembelajaran Statistika Dasar Bermuatan Pendidikan Karakter Dengan Metode Problem Based Learning. Jurnal PP, 1(2), 159-165.

Fitriana, M., \& Ismah. (2016). Pengaruh 
Model Pembelajaran Auditory Intellectually Repetition Terhadap Hasil Belajar Matematika Siswa Ditinjau Dari Kedisiplinan Siswa. Jurnal Pendidikan Matematika Dan Matematika, 2(1), 59-68.

Frey, A. J. R. G., \& Loots, M. T. (2014). Statistical Software (R, SAS, SPSS, and Minitab) for Blind Student and Practitioners. Journal of Statistical Software, 58(1), 1-25.

Jagantara, I. M. W., Prof. Dr. Putu Budi Adnyana, M. S., \& Dr. Ni Luh Putu Manik Widiyanti, S. S. (2014). Pengaruh Model Pembelajaran Berbasis Proyek (Project Based Learning) Terhadap Hasil Belajar Biologi Ditinjau Dari Gaya Belajar Siswa SMA. Jurnal Pendidikan Dan Pembelajaran IPA Indonesia, 4(1).

Kania, N., Kartimi, \& Mulyani, A. (2013). Penerapan Pembelajaran Biologi Berbasis Sains Lokal Melalui Budaya Paraji Terhadap Hasil Belajar Siswa Pada Pokok Bahasan Sistem Reproduksi Kelas XI di SMA Negeri Jatiwangi. Jurnal Scientiae Educatia, 2(2), 1-18.

Lipianto, D., Budiarto, M. T., Matematika, J., Surabaya, U. N., Matematika, J., \& Surabaya, U. N. (2013). Analisis kesalahan siswa dalam menyelesakan soal yang berhubungan dengan persegi dan persegipanjang berdasarkan taksonomi solo plus pada kelas vii. Mathedunesa, 2(1).

Maryati, I., \& Priatna, N. (2017). Analisis Kesulitan dalam Materi Statistika Ditinjau dari Kemampuan Penalaran dan Komunikasi Statistis. Jurnal Prisma, 6(2).

Niati, A., Soelistiyono, A., \& Ariefiantoro, T. (2019). Pengembangan Kemampuan Sumber Daya Manusia Melalui Pelatihan Komputer Microsoft Excel Untuk Meningkatkan Kinerja Perangkat Desa Mranggen. E-Dimas, 10(1), 105-110.

Prihartini, \& Mediatati, N. (2013).
Perbedaan Pengaruh Metode Pembelajaran Kooperatif Tioe TSTS ( Two Stay Two Stray) Dan Metode Ceramah Terhadap Hasil Belajar. Satya Widya, 29(2), 127-133.

Santi, W. (2016). Eksperimentasi Model Pembelajaran Student Facilitator and Explaining (SFE) Terhadap Hasil Belajar ditinjau dari Kecerdasan Linguistik. Al-Jabar, 7(2), 267-274.

Sari, E. N., Ridlo, S., \& Utami, N. R. (2016). Pengaruh Model Pembelajaran Discovery Learning Dengan Mind Mapping Terhadap Hasil Belajar Siswa Pada Materi SEL di SMA. Unnes Science Education Journal, 5(3), 1403-1407.

Septiono, D., \& Darminto, B. P. (2014). Perbandingan Pembelajaran

Matematika Dengan Hypnoteaching Dan Ekspositori Terhadap Hasil Belajar Pada Materi Limit Fungsi. Ekuivalen, 12(2), 214-219.

Susanti, Musdi, E., \& Syarifuddin, H. (2017). Pengembangan Perangkat Pembelajaran Matematika Materi Statistik Berbasis Penemuan Terbimbing Untuk Meningkatkan Kemampuan Pemecahan Masalah Matematis Materi Statistika. Jurnal JNPM ( Jurnal Nasional Pendidikan Matematika ), 1(2), 305-319.

Syaifulloh, A. (2016). Pengaruh Strategi Problem-Based Learning (PBL) terhadap Motivasi dan Hasil Belajar Peserta Didik pada Mata Pelajaran Fiqih di MA Khozinatul 'Ulum Blora Jawa Tengah. Wahana Akademika, 3(2), 121-136.

Tayeb, T., Idris, R., \& Andi. (2014). Peranan Mata Kuliah Statistika Dalam Memahami Mata Kuliah Metodologi Penelitian Bagi Mahasiswa Jurusan Pendidikan Matematika Fakultas Tarbiyah Dan Keguruan Uin Alauddin Makassar. Mapan : Jurnal Matematika Dan Pembelajaran, 2(1), 1-18.

Yenni. (2017). Pengembangan Bahan Ajar Statistika Untuk Mengembangakan 
Desimal, 2 (3), 2019 - 279

Novalia

Kemampuan Pemahaman Matematis

Journal of Mathematics Education,

Mahasiswa Pendidikan Anak Usia Science And Technology, 2(1), 90-102.

Dini Pada Mata Kuliah Statistika. 